\title{
Molecular identification, expression and prognostic role of estrogen- and progesterone receptors in head and neck cancer
}

\author{
J. LUKITS $^{1 *}$, É. REMENÁR ${ }^{2 *}$, E. RÁSÓ ${ }^{1}$, A. LADÁNYI ${ }^{1}$, M. KÁSLER ${ }^{2}$ and J. TÍMÁR ${ }^{1}$ \\ Departments of ${ }^{1}$ Tumor Progression and ${ }^{2}$ Head and Neck Surgery, National Institute of Oncology, Budapest, Hungary
}

Received August 7, 2006; Accepted October 5, 2006

\begin{abstract}
The aims of this study were to assess the sex hormone receptor status of head and neck (HNC) cancers. Frozen surgical samples $(n=67)$ of $H N C$ patients were analyzed. Protein expression of estrogen receptor (ER) $\alpha$, ERß and progesterone receptor $(\mathrm{PgR})$ of tumor cells was determined by immunocytochemistry. Data were confirmed at mRNA level by nested-PCR and sequencing. ER and PgR expressions confirmed by PCR analysis were frequent in HNC: 50.7 and $49.3 \%$ respectively. Concerning the ER isoforms, ER $\alpha$ expression was predominant over ERß in both of oral cavityas well as laryngeal/hypopharyngeal (LH) cancers. The $\delta 3$ splice variant of $\mathrm{ER} \alpha$ was detected at low frequency, while the $\delta 5$ splice variant of ERß was frequent in HNC. The incidence of functional receptor expression (coexpression of ER and $\mathrm{PgR}$ ) was relatively frequent also in $\operatorname{HNC}(27 / 67,40.3 \%)$ which was independent of the anatomical location of the tumor. Sex hormone receptor expressions did not affect survival of HNC patients, however, in the LH cancer subgroup ER expression was associated with a trend of shortened survival $(\mathrm{p}=0.0636$, Mantel-Cox generalized savage). $\mathrm{ER} \alpha, \beta$ and $\mathrm{PgR}$ expressions are frequent in HNC and may affect the prognosis of the disease, at least in case of LH cancers.
\end{abstract}

\section{Introduction}

Head and neck cancer is an increasing problem in certain geographic areas of the world, especially in central-east Europe (1). Although this cancer is characterized by a relatively simple biology (loco-regional spreading for an extended period of the disease) the 3-year survival rates are disturbingly low $(2,3)$. A moderate development was achieved in the

Correspondence to: Dr József Tímár, Department of Tumor Progression, National Institute of Oncology, Rath Gy. u. 7-9, Budapest H-1122, Hungary

E-mail: jtimar@oncol.hu

${ }^{*}$ Contributed equally

Key words: head and neck cancer, sex hormone receptor, immunocytochemistry, PCR, prognosis combined chemo-radiation therapy of this tumor in the past years in addition to the traditional surgical management (3).

Our knowledge significantly expanded in the past decade on the molecular mechanism of the carcinogenesis of the head and neck cancer by the identification of disturbed controlling processes affecting cancer cell survival and proliferation. On the other hand, the mechanism of progression of head and neck cancer is largely unknown. Altered stromal interactions, tumor-induced neoangiogenesis and neo-lymphangiogenesis (2) as well as immunological interactions (4) all have been shown to be involved. Concerning the invasive potential of squamous cancer cells down-modulation of cell adhesion molecules and upregulation of various proteases have been described to play a significant role although the complexity of the process remains largely unexplored (2).

Endocrine milieu is an important factor of tumor progression in case of cancers characteristically expressing sex hormone receptors such as breast (5), prostate (6) and endometrial cancer (7). The sex hormone receptors are expressed outside the sexual organs such as the vascular endothelium (8) the larynx (9) or the lung epithelium (10). Accordingly, it is feasible to expect ectopic/illegitime sex hormone receptors in various cancer types.

Reports on sex hormone receptor expression in head and neck cancer is in the literature for more than 20 years. The majority of the earlier publications provided evidence for the expression of ER and PgR protein by HNC based on ligand binding assays (12-15). In a small minority of the studies ER and $\mathrm{PgR}$ protein was identified biochemically, but none of these above mentioned studies demonstrated conclusively that HNC cancer cells themselves are expressing the authentic receptor(s). ER and PgR proteins were detected in HNC cells based on small patient cohorts $(12,15)$. Therefore our aim was to determine the sex hormone receptor status of HNC by using molecular and immunocytochemical approach in a larger series of patients with known 3-year follow-up period.

\section{Patients and methods}

Patients. Operated HNC patients $(n=67)$ were enrolled to this study. The protocol was approved by the Institutional Ethics Committee and formal consent of the patients was obtained. The patient characteristics are summarized in Table I. Overwhelming majority of the patients were males (56/67). The anatomical localization of the cancers was uneven in respect of the head and neck region since the majority of the 
Table I. Clinical data of HNC patients.

\begin{tabular}{|c|c|}
\hline Number of patients & 67 \\
\hline Age $[$ mean $\pm \mathrm{SD}$, range (years) $]$ & $60.4 \pm 9.7(42-86)$ \\
\hline $\operatorname{Sex}(M / F)$ & $56 / 11$ \\
\hline \multicolumn{2}{|l|}{ Localization } \\
\hline Oral cavity & $24 / 67(35.8 \%)$ \\
\hline Larynx & $32 / 67(47.8 \%)$ \\
\hline Hypopharynx & $11 / 67(16.4 \%)$ \\
\hline Histology & Squamous cell cancer \\
\hline \multicolumn{2}{|l|}{ T stage } \\
\hline 1 & $1 / 67 \quad(1.5 \%)$ \\
\hline 2 & $20 / 67(29.8 \%)$ \\
\hline 3 & $34 / 67(50.7 \%)$ \\
\hline 4 & $12 / 67(17.9 \%)$ \\
\hline \multicolumn{2}{|l|}{$\mathrm{N}$ stage } \\
\hline 0 & $43 / 67(64.2 \%)$ \\
\hline+ & $24 / 67(35.8 \%)$ \\
\hline \multicolumn{2}{|l|}{ M stage } \\
\hline 0 & $67 / 67$ \\
\hline+ & 0 \\
\hline \multicolumn{2}{|l|}{ Grade } \\
\hline 1 & $11 / 67(16.3 \%)$ \\
\hline 2 & $36 / 67(53.8 \%)$ \\
\hline 3 & $20 / 67(29.9 \%)$ \\
\hline
\end{tabular}

HNC, head and neck cancer; M, male; F, female.

tumors located in the laryngeral and hypopharyngeal area $(43 / 67)$ while one third $(35.8 \%)$ located in the oral cavity. There were no oropharyngeal cancers enrolled to this study. Beside the routine histopathologic work-up of the surgically removed samples, tumor tissue was deep-frozen in isopentane/liquid nitrogen and stored at $-70^{\circ} \mathrm{C}$.

HNC cell lines. PE/CA-PJ15 human tongue squamous cell carcinoma and PE/CA-PJ41 human oral squamous cell carcinoma cell lines were obtained from ECACC and were cultured in DMEM supplemented with $10 \%$ fetal bovine serum and RNA was isolated from confluent cultures as described below.

Immunocytochemistry. Five-micron frozen sections were prepared from HNC tumor bank samples, fixed in $\mathrm{MetOH}$ washed in PBS and stored at $4^{\circ} \mathrm{C}$ overnight. Sex hormone receptors were identified by immunocytochemistry using mouse monoclonal anti-human ER $\alpha$ (dilution 1:50, Dako, Glostrup, Denmark), anti-human ER $\alpha$ (dilution 1:30, Novocastra,
Newcastle upon Tyne, UK), rabbit polyclonal anti-human ERß (dilution 1:30, Novocastra) and mouse monoclonal antihuman PgR (dilution 1:50, Dako). The specifically bound antibodies were revealed by appropriate biotinylated secondary antibodies (1:100, Amersham, Buckinghamshire, UK) and Streptavidin-Texas-Red complex (Amersham, 1:100 dilution). Section were stained with Hoechst dye (1:10000 dilution, Molecular Probes, Eugene, OR) and mounted with Vectashield (Vector, Burlingame, CA) 1:1 mixture. Samples were evaluated in a Nikon Eclipse-600 epifluorescent microscope (Tokyo, Japan) equipped with a Spot-Jr digital camera (Diagnostic Instruments, Sterling Heights, MI). HNC samples were scored positive for any sex hormone receptors when $>10 \%$ of cancer cells were positive and the data confirmed by PCR at mRNA level.

Nested-PCR. Total RNA was isolated from the frozen homogenized tumor samples using TRI Reagent ${ }^{\mathrm{TM}}$ (Sigma $^{\circledR}$ ) according to the manufacturer's instructions. Possible DNA contamination was eliminated using Turbo DNA-free ${ }^{\mathrm{TM}}$ kit $\left(\right.$ Ambion $^{\circledR}$ ). For reverse transcription $1 \mu \mathrm{l}$ of $10 \mathrm{mM}$ dNTP mix (Finnzyme ${ }^{\circledR}$ ) and $1 \mu 1$ of Random primer-oligo dT combination for a final concentration of $2.5 \mu \mathrm{M}$ was added and $2 \mu \mathrm{g}$ of the purified total RNA was used. After incubating at $70^{\circ} \mathrm{C}$ for $10 \mathrm{~min} 2 \mu \mathrm{l}$ of $10 \mathrm{X}$ M-MLV Reverse Transcriptase Buffer (Finnzyme), $1 \mu 1$ of M-MLV Reverse Transcriptase (200 U/ $\mu 1$, Finnzyme), $0.5 \mu 1$ RNase Inhibitor (40 U/ $\mu 1$, Promega ${ }^{\circledR}$ ) and $6.5 \mu 1$ DEPC treated water was added to the final volume of $20 \mu 1$ than incubated at $37^{\circ} \mathrm{C}$ for $50 \mathrm{~min}$ and $85^{\circ} \mathrm{C}$ for $10 \mathrm{~min}$. The occurrence of reverse transcription was checked by carrying out polymerase chain reaction with 3 -actin primers (GTG GGG CGC CCC AGG CAC CCA, CTC CTT AAT GTC ACG CAC GAT TTC) as a housekeeping gene. RNA of the same sample was used as negative control for detection of DNA contamination and DEPC treated water as non-template control.

To detect ER $\alpha, E R ß$ and PGR expressions nested PCR reactions were carried out. The first PCR reaction mixture contained 2.5 $\mu 1$ 10X PCR puffer $+\mathrm{Mg}^{2+}\left(\right.$ DyNazyme $\left.^{\mathrm{TM}}\right), 2 \mu 1$ dNTP mix (2.5 mM each), $0.4 \mu 1$ DNA polymerase (DyNazyme $\left.^{\mathrm{TM}}, 2 \mathrm{U} / \mu 1\right), 2.5-2.5 \mu 1$ of the outer primers (ER $\alpha$ : CTC AGC ATC CAA CAA GGC AC, AAG GAG ACT CGC TAC TGT GC, ERß: TCA CTT CTG CGC TGT CTG CAG CG, CCT GGG TCG CTG TGA CCA G, PGR: AAG ACG CAG GAC CAG CAG, CCT CAA CCT CCA CCG CAG), $2 \mu 1$ of the cDNA and $13.1 \mu 1$ DEPC treated water for the final volume of $25 \mu$. The cycling conditions were: $94^{\circ} \mathrm{C}$ for $1 \mathrm{~min}, 55^{\circ} \mathrm{C}$ for $1 \mathrm{~min}, 72^{\circ} \mathrm{C}$ for $1 \mathrm{~min}$ for 30 cycles, $72^{\circ} \mathrm{C}$ for $7 \mathrm{~min}$.

The nested PCR reaction mixture contained $2.5 \mu 110 \mathrm{X}$ PCR puffer $+\mathrm{Mg}^{2+}$ (DyNazyme), $2 \mu \mathrm{l}$ dNTP mix $(2.5 \mathrm{mM}$ each), $0.2 \mu 1$ DNA polymerase (DyNazyme, $2 \mathrm{U} / \mu 1$ ), 2.5-2.5 $\mu 1$ of the inner primers (ER $\alpha$ : ATG ACT ATG CTT CAG GCT ACC A, TTG GCA GCT CTC ATG TCT CC, ERß: GCC CAA GAG AAG TGG CGG CCA CG, AAA CCT TGA AGT AGT TGC CAG GAG C, PGR: GCT CTT GGT GCC TGT TTG G, AGA GCC ATC CTC CTC CTC AA) $1 \mu 1$ of the first PCR reaction product and $14.3 \mu 1$ DEPC treated water for the final volume of $25 \mu 1$. The cycling conditions were: $94^{\circ} \mathrm{C}$ for $1 \mathrm{~min}, 55^{\circ} \mathrm{C}$ for $1 \mathrm{~min}, 72^{\circ} \mathrm{C}$ for $1 \mathrm{~min}$ for 
30 cycles, $72^{\circ} \mathrm{C}$ for $7 \mathrm{~min}$. PCR products were separated on a $2 \%$ agarose gel and detected with Gel Doc $2000\left(\right.$ Bio-Rad $\left.^{\circledR}\right)$ after ethidium bromide staining.

Nested PCR products originated from samples of randomly chosen patients were re-isolated from the agarose gel (High Pure PCR Product Purification Kit, Roche, Mannheim, Germany) in the case of all receptor types and all bands. The DNA sequences were determined by Big Dye Terminator cycle sequencing on Applied Biosystems 3130 Genetic Analyzer (Applied Biosystems).

Statistical analysis. Data were evaluated by $\chi^{2}$, Kaplan-Meier and Mantel-Cox general salvage methods.

\section{Results}

Characterization of the patient cohort. Histological diagnosis of all HNC samples was squamous cell carcinoma, predominantly of Grade II, the majority of which was not metastatic (NOM0) (Table I). About half of the cases located in the laryngeal area, third of the cases were in the oral cavity and the rest was in the hypopharynx.We used two groups, oral cavity cancers and laryngeal/hypopharyngeal (LH) tumors due to the close anatomical vicinity.

Sex hormone receptor expression in normal oral and glottic mucosa. Attempts to detect ER or PgR protein in the normal glottic or oral tissue in paraffin-embedded material were unsuccessful using normal breast tissue as positive control. Therefore, ten samples of fresh frozen normal glottic tissue was also analyzed for sex hormone receptor expression by immunocytochemistry. ER $\alpha$ protein was detected in the cytoplasm of the normal squamous epithelial cells (Fig. 1A), while ERß protein was predominantly detected in the cytoplasm of glandular epithelial cells (Fig. 1B). These data were confirmed by nested PCR analysis, since normal oral or glottic mucosal tissues expressed ER $\alpha, E R ß$ and PgR mRNA in 7 out of the 10 cases (data not shown) confirming previous protein data $(11,15)$.

Detection of sex hormone receptors in HNC. ER or PgR receptors were not detectable at protein level in paraffinembedded $\mathrm{HNC}$ tissues using ER and $\mathrm{PgR}^{+}$breast cancer tissue as positive control. Therefore, immunohistochemistry was performed on fresh frozen samples of the surgically removed tumors using monospecific anti-receptor antibodies. In case of the positive immunocytochemical reaction ( $>10 \%$ reactivity), nested-PCR technique was used to confirm the expression of the receptors at mRNA level and the authenticity of the reaction was further verified by sequencing.

Immunocytochemistry demonstrated frequent nuclear $\mathrm{ER} \alpha$ positivity in HNC cancer cells (Fig. 1C) although cytoplasmic reaction was also observed at lower frequency. ERß was predominantly found in the cytoplasm of cancer cells (Fig. 1D) although nuclear reaction was also detected at lower frequency. PgR protein was found in both the nucleus and cytoplasm of cancer cells (Fig. 1E). It is of note, that stromal components of HNC did not show sex hormone receptor protein reactivity by this approach (Fig. 1).
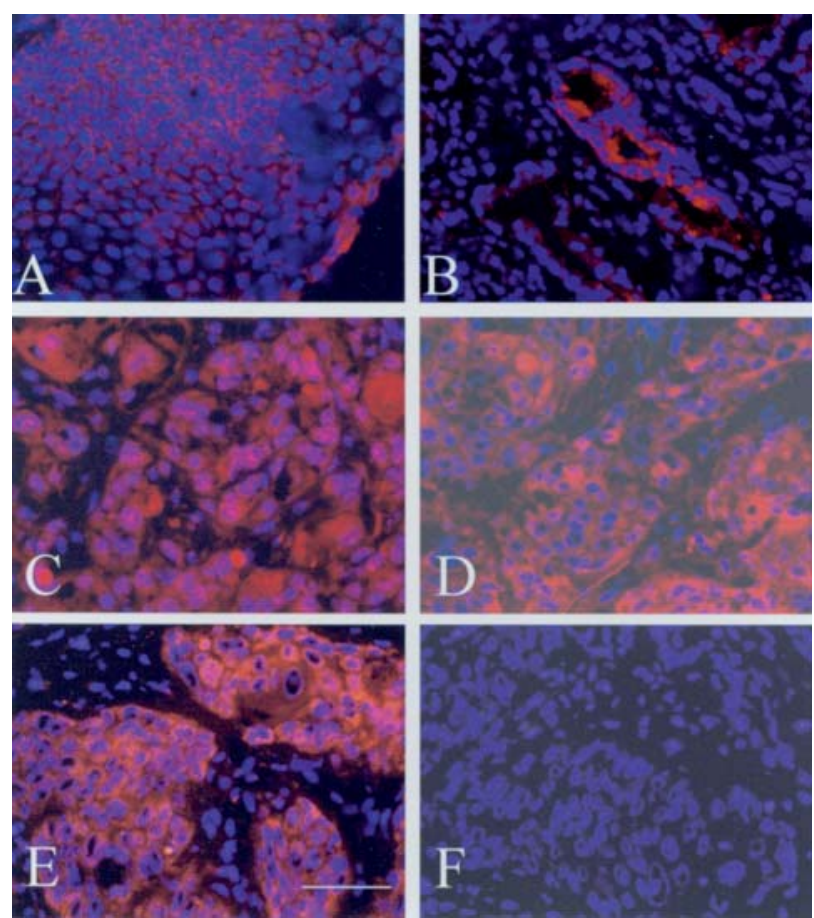

Figure 1. Immunocytochemistry of hormone receptors in HNC. Cell nuclei are stained blue (DAPI). Normal glottic tissue is characterized by cytoplasmic $\mathrm{ER} \alpha$ labeling of epithelial cells of the covering mucosa (red signal, A), while the cytoplasm of the glottic glandular epithelial cells was positive for ERß (red signal, B). C, Nuclear expression of ER $\alpha$ protein in HNC cells. Note the overlapping red and blues signals (pink colour) as well as an intense cytoplasmic label. D, Expression of ERß protein in HNC cells. Note the strong cytoplasmic red signal and the overlapping red and blue signals in tumor cells. E, Predominant cytoplasmic expression of PgR protein in HNC cells (red signal). F, Negative control. HNC tissue was processed as in A-E, except omitting the primary anti-receptor antibody. Nuclei are labeled with DAPI (blue). Bar, $20 \mu \mathrm{M}$.

Nested-PCR analysis of the mRNA extracted from cancer tissue detected ER $\alpha$ and occasionally its $\delta 3$ splice variant (Fig. 2A). ERß was found to be frequently expressed in two isoforms, a wt and the $\delta 5$ splice variant, while PgR was detected in the authentic wild-type form (Fig. 2A), all confirmed by sequencing (data not shown). Furthermore, 2 human HNC cell lines PE/CA-PJ15 and -PJ41 cultured in vitro were also found to express $E R \alpha$ without the expression of ERß and $\mathrm{PgR}$ as detected by nPCR. It is of note, that PJ15 expressed the $\delta 3$ variant of $E R \alpha$ as well (Fig. 2B).

About half of HNC cases expressed ER and PgR (34/67 and 33/67, respectively, Table II). While the frequency of ER expression was higher in oral/tongue cancers compared to glottic/hypopharyngeal ones (58.3 versus $46.5 \%$ respectively), the $\mathrm{PgR}$ expression was very similar in the two locations. Concerning the ER isoforms, $\mathrm{ER} \alpha$ was more prevalent compared to ERß at both anatomical locations.

Solitaire hormone receptor expression was a rare phenomenon in HNC characterizing a small subset of glottic/hypopharyngeal cancers exclusively (6/43). Since PgR expression is regulated by ER activity, co-expression of ER(s) with PgR is considered a molecular sign of functional ER expression (5). According to this assumption, functional ER expression was a frequent characteristic of HNC proven to be independent of the anatomical location $(27 / 67,40.3 \%$, Table III). 
A

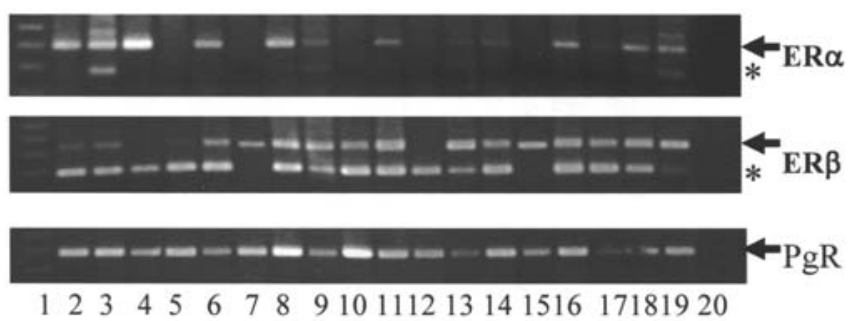

B

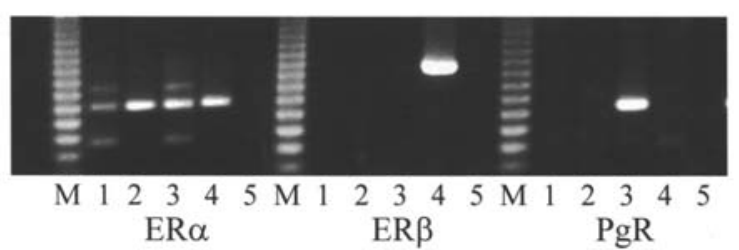

Figure 2. Expression of ER and PgR at mRNA level in HNC tissue and HNC cell lines. A, HNC tissues. Arrows indicate the authentic wt bands: $\mathrm{ER} \alpha=304 \mathrm{bp}, \mathrm{Er} \beta=429 \mathrm{bp}$. Asterisk, splice variants: $\Delta 3$ (ER $\alpha=287 \mathrm{bp}), \Delta 5$ $(E R ß=269$ bp). 1, Base pair marker. 2-20, HNC sample ID. PgR, progesterone receptor. B, Human PE/CA-PJ15 and -PJ41 cell lines. Lane 1, PJ15; lane 2 , PJ41; lane 3 (MCF7 breast cancer); and lane 4 (OVCAR ovarian cancer cell line) are positive controls; lane 5, negative control $\left(\mathrm{H}_{2} \mathrm{O}\right)$.

Prognostic significance of sex hormone expression in HNC. Neither ER nor PgR expression affected survival of HNC patients: 36 month survival rates were in the range of 55-70\%. Furthermore, functional expression of ER $(\mathrm{ER}+\mathrm{PgR})$ in HNC did not affect the survival either. Since oral cavity cancer cases were in a minority in this cohort $(35.8 \%)$ where receptor positive and negative groups of patients are critically unbalanced, we performed a subgroup analysis on the LH cancers. Kaplan-Meier analysis of the data indicated that LH cancer patients with ER expression (ER $\alpha, \mathrm{ER} \beta$ or both) in their tumors are characterized by a trend of poorer survival compared to negative cases and Mantel-Cox regression salvage analysis of the survival data further supported this ( $<<0.0636$, Fig. 3A). On the other hand, $\operatorname{PgR}$ expression status did not affect survival of LH cancer patients (Fig. 3B). Comparison of the $\mathrm{ER}^{+}$and ER- LH cancers indicated that the T3 and grade 3 cases were overrepresented in the $\mathrm{ER}^{+}$group, while there was no difference in the N stage (Table IV). Since previous studies suggested that estrogens might have a mitogenic effect on HNC cells,
A
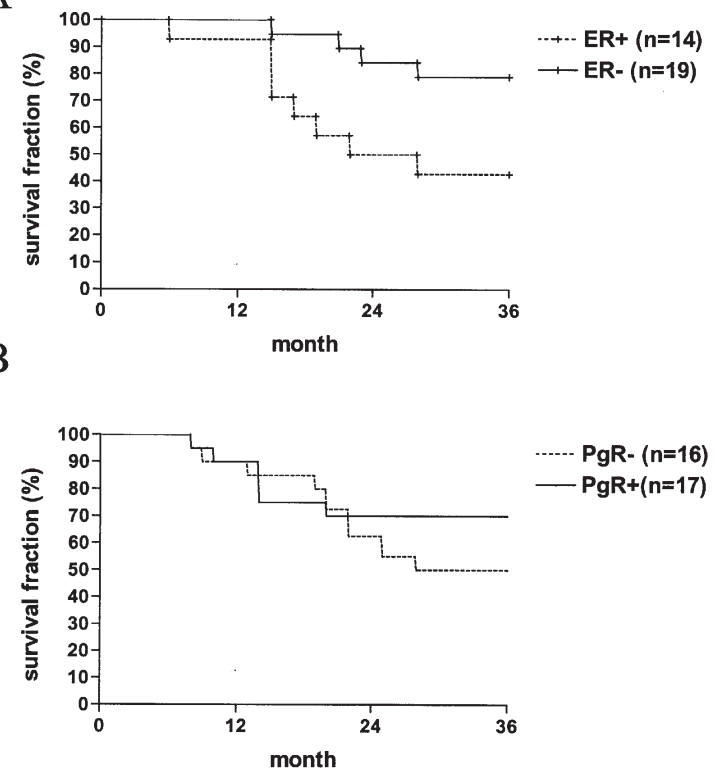

Figure 3. Kaplan-Meier analysis of survival of laryngeal/hypopharyngeal cancer patients. A, Survival of patients with $\mathrm{ER}^{+}$cancer is different from those of $\mathrm{ER}^{-}$ones $(\mathrm{p}<0.0636)$. B, There is no survival difference in patients with PgR expressing cancers $(\mathrm{p}=0.689)$. Mantel-Cox regression salvage analysis.

Table III. Functional hormone receptor status of HNC ( $n=67)$.

\begin{tabular}{|c|c|c|c|}
\hline $\begin{array}{l}\text { Receptor } \\
\text { status }\end{array}$ & $\begin{array}{l}\text { Oral } \\
\text { cavity } \\
(n=24)\end{array}$ & $\begin{array}{c}\text { Laryngeal/ } \\
\text { hypopharyngeal } \\
(\mathrm{n}=43)\end{array}$ & $\begin{array}{l}\text { HNC } \\
(n=67)\end{array}$ \\
\hline $\mathrm{HR}^{+}$ & $0 / 24 \quad(0 \%)$ & $6 / 43(13.9 \%)$ & $6 / 67 \quad(8.9 \%)$ \\
\hline $\mathrm{FHR}^{+}$ & $9 / 24(41.7 \%)$ & $18 / 43(41.9 \%)$ & $27 / 67(41.8 \%)$ \\
\hline
\end{tabular}

$\mathrm{HNC}$, head and neck cancer. $\mathrm{HR}^{+}$, single hormone receptor positivity. $\mathrm{FHR}^{+}, \mathrm{ER} \alpha$ and/or ERß positivity with concomitant $\mathrm{PgR}$ positivity. Receptor positivity was determined by IHC and was confirmed by PCR.

we tested the effect of estradiol on the proliferation of -PJ15 and PJ41 cells in vitro. Preliminary data indicated that 3-day in vitro incubation of $\mathrm{HNC}$ cells with $1 \mu \mathrm{M}$ estradiol

Table II. Sex hormone receptor status of HNC ( $n=67)$.

\begin{tabular}{lccrrr}
\hline & $\mathrm{n}$ & $\mathrm{ER} \alpha(\%)$ & $\mathrm{ERß}(\%)$ & $\mathrm{ER}^{\mathrm{a}}(\%)$ & $\operatorname{PgR}^{\mathrm{a}}(\%)$ \\
\hline HNC & 67 & $28 / 67(41.8)$ & $19 / 67(28.4)$ & $34 / 67(50.7)$ & $33 / 67(49.3)$ \\
Oral cavity & 24 & $12 / 24(50.0)$ & $8 / 24(33.3)$ & $14 / 24(58.3)$ & $12 / 24(50.0)$ \\
Laryngeal/hypopharyngeal & 43 & $16 / 43(37.2)$ & $11 / 43(25.6)$ & $20 / 43(46.5)$ & $21 / 43(48.8)$ \\
\hline
\end{tabular}

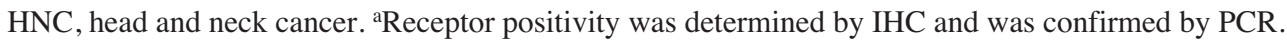


Table IV. Clinical characteristics of the ER $\mathrm{ER}^{+}$laryngeal/ hypopharyngeal cancer subgroup $(n=43)$.

\begin{tabular}{lcc}
\hline Cancer type & ER+ $(\mathrm{n}, \%)$ & ER- $(\mathrm{n}, \%)$ \\
\hline Sex $(\mathrm{F} / \mathrm{M})$ & $3 / 20(15.0 \%)$ & $4 / 23(17.4 \%)$ \\
T stage & & \\
1 & $0 / 20(0.0)$ & $1 / 23 \quad(4.3 \%)$ \\
2 & $1 / 20(5.0)$ & $4 / 23(17.4 \%)$ \\
3 & $16 / 20(80.0)$ & $8 / 23(43.5 \%)$ \\
4 & $3 / 20(15.0)$ & $7 / 23(34.8 \%)$ \\
$\mathrm{N}$ stage & & \\
- & $10 / 20(50.0)$ & $13 / 23(56.5)$ \\
+ & $10 / 20(50.0)$ & $8 / 23(43.5)$ \\
Grade & & \\
1 & $3 / 20(15.0)$ & $3 / 23 \quad(8.7)$ \\
2 & $7 / 20(35.0)$ & $12 / 23(56.5)$ \\
3 & $10 / 20(50.0)$ & $5 / 23(34.8)$ \\
\hline
\end{tabular}

$\mathrm{F}$, female; $\mathrm{M}$, male $\mathrm{N}^{-}$, no lymph node metastasis; $\mathrm{N}^{+}$, involvement of min. one node.

administered in serum-free conditions induced a 50\% stimulation of cell proliferation in both PJ cell lines (data not shown) supporting previous data on the mitogenic effects of estrogens in HNC cells $(25,27)$.

\section{Discussion}

Debate on the role of sex hormones in HNC has a long history. Sex hormone receptors were demonstrated previously in laryngeal tissue $(9,14)$ using radioimmunoassay technique. Furthermore, the majority of the ligand binding assays demonstrated specific sex hormone-binding sites in HNC (12-15), although negative results also exist $(11,16)$. The first indication for nuclear hormone receptor expression in laryngeal cancer was published more than 15 years ago (12), and immunoblotting study supported these data (17), but confirmation of these observations at molecular level were missing. Here we have demonstrated for the first time on a larger series of HNC samples, that both oral cavity, laryngeal or hypopharyngeal cancers express authentic ERs (both $\alpha$ and $\beta$ isoforms) as well as $\mathrm{PgR}$ in $~ 50 \%$ of cases identified both at mRNA as well as protein levels. Our analysis indicated the expression of both the wild-type and splice variants of ER $\alpha$ and ERß receptors, $\delta 3$ and $\delta 5$, respectively (18). We have also demonstrated, that the sex hormone receptors are localized to cancer cells themselves since we have not detected receptors in the tumoral stroma. It is of note, that level of receptor expressions is low in HNC at mRNA and protein levels since nested PCR was necessary to detect transcripts and frozen tissues for immunocytochemistry. The solitary sex hormone receptor expression in HNC was a rare event, since in the majority of positive cases (41.8\%) ER expression was combined with $\mathrm{PgR}$ expression: $\mathrm{ER} \alpha+\mathrm{PgR}$ was the predominating fenotype followed by $E R \alpha / \beta+P g R$. This is an important finding of our study, since coexpression of ERs with $\mathrm{PgR}$ is considered as an indirect sign of functional ER expression in other tissues and cancers such as breast cancer $(5,7)$. Accordingly, our data suggest a functional ER expression in a significant proportion of HNC ( 40\%). We have also found that anatomical location of the HNC (oral cavity, larynx or hypopharynx) did not affect this phenotype. Analysis of human HNC cell lines further supported our observations demonstrating the expression of ERs and PgR, confirming previous in vitro observations $(25,26)$. Furthemore, our preliminary data also agree with those previous reports, that estrogen(s) might be mitogenic in vitro for human HNC cell lines expressing authentic ER (25-27).

What could be the significance of functional ER expression in HNC? HNC more frequently develops in alcoholic patients whose chronic liver disease is a common clinical complication. Deteriorating liver function is frequently reflected in alteration of sex hormone metabolism involving testosterone and estrogen $(14,19)$. On the other hand, the majority of HNC patients are males, characterized theoretically by testosteronerich sex hormone-microenvironment. Analysis of a large series of HNC patients compared to control and alcoholic populations revealed significantly elevated FSH and LH levels, whereas estrogen-elevation and testosterone decrease characterized the alcoholic patients $(14,19)$. In the same set of patients increased FSH and decreased testosterone levels predicted poor overall survival of HNC (14). In another study on tongue cancer patients elevated prolactin levels have been found to be a marker of poor prognosis and interestingly, the intratumoral expression of prolactin receptors were also discovered by molecular techniques (20).

PgR expression in laryngeal cancer was found to correlate with cathepsin D expression (17), the latter of which was shown to be involved in tumor progression of HNC (2). ER signaling has been shown to cooperate with growth factor signaling (21). It is now well established that EGFR affects ER expression and vice versa (22). One of the molecular markers of HNC is the constitutive expression of EGFR (23). It is tempting to speculate, that the constitutive expression of EGFR in HNC may control ER and/or PgR expression (24). The functional significance of ER expression in HNC was demonstrated in vitro when the antiestrogen tamoxifen inhibited cell proliferation and induced apoptosis in $\mathrm{ER}^{+} \mathrm{HNC}$ cell lines $(25,26)$. On the other hand, estradiol administration into SCID mice stimulated laryngeal cancer growth (27).

Our data on the effect of ER expression on HNC progression support these experimental data. The survival of $\mathrm{LH}$ cancer patients with ER positive tumors tended to be poorer compared to those with ER negative tumors, but the differences did not reach the level of statistical significance $(\mathrm{p}=0.0636)$, suggesting that ER expression and/or the estrogen-activated ER in this subgroup of HNC may act as a progression promoting factor. However, further studies on larger HNC cohort is necessary to confirm these preliminary data. It also needs further study, if ER plays similar role in oral cavity cancers as in case of laryngeal/hypopharyngeal ones, but the small size of our cohort and the imbalance between the 
$\mathrm{ER}^{+/-}$tumors did not allow such an analysis. On the other hand, frequent expression of ER, especially together with $\mathrm{PgR}$, in HNC suggests that antiestrogens, ER- or aromatase inhibitors may have a therapeutic role in the clinical management of HNC, independent of the sex of the patients. Clinical studies are urgently needed to explore these options.

\section{Acknowledgements}

The authors express their thanks to István Gaudi for the help in statistical analysis of data. This work was supported by the Ministry of Education (NKFP1a-0024-05).

\section{References}

1. Döbrössy L: Cancer mortality in central-eastern Europe: facts behind the figures. Lancet Oncol 3: 374-381, 2002.

2. Tímár J, Csuka O, Remenár É, et al: Progression of head and neck squamous cell cancer. Cancer Metastasis Rev 24: 107-127, 2005.

3. Lamont EB and Vokes EE: Chemotherapy in the management of squamous-cell carcinoma of the head and neck. Lancet Oncol 2: $261-269,2002$

4. Whiteside TL: Immunobiology of head and neck cancer. Cancer Metastasis Rev 24: 95-105, 2005.

5. Jensen EV and Jordan C: The estrogen receptor: a model for molecular medicine. Clin Cancer Res 9: 1980-1989, 2003.

6. Mohler JL, Gregory CW, Ford III OH, et al: The androgen axis in recurrent prostate cancer. Clin Cancer Res 10: 440-448, 2004.

7. Pearce ST and Jordan VC: The biological significance of estrogen receptors alpha and beta in cancer. Crit Rev Oncol Hematol 50: 3-22, 2004.

8. Venkov CD, Rankin $\mathrm{AB}$ and Vaughan DE: Identification of authentic estrogen receptor in cultured endothelial cells. A potential mechanism for steroid hormone regulation of endothelial function. Circulation 94: 727-733, 1996.

9. Marsigliante S, Muscella A, Storelli L and Storelli C: Human larynx expresses isoforms of the oestrogen receptor. Cancer Lett 99: 191-196, 1996.

10. Omoto Y, Kobayashi Y, Nishida K, et al: Expression, function and clinical implication of the estrogen receptor beta in human lung cancer. Biochem Biophys Res Commun 285: 340-347, 2001.

11. Schuller DE, Abou-Issa H and Parrish R: Estrogen and progesterone receptors in head and neck cancer. Arch Otolaryngol 110: 725-827, 1984.

12. Ferguson BJ, Hudson WR and McCarty KS Jr: Sex steroid receptor distribution in the human larynx and laryngeal carcinoma. Arch Otolaryngol Head Neck Surg 113: 1311-1315, 1987.
13. Resta L, Marsigliante S, Leo G, et al: Molecular biopathology of metaplastic, dysplastic, and neoplastic larlyngeal epithelium. Acta Otolaryngol Suppl 527: 39-42, 1997.

14. Remenár É, Számel I, Buda B, et al: 'Why men?' Hormones and hormone receptors in male head and neck cancer patients. In: Advances in Laryngology in Europe. Klainsasser O, Glanz H and Olofsson J (eds). Elsevier, pp137-140, 1997.

15. Ögretmenoglu O and Ayas K: Laryngeal carcinoma and estrogen receptor analysis in patients after long-term follow-up. Eur Arch Otorhinolaryngol 255: 457-461, 1998.

16. Hagedorn HG and Nerlich AG: Analysis of sex-hormone-receptor expression in laryngeal carcinoma. Eur Arch Otohinolaryngol 259: 205-210, 2002.

17. Marsigliante S, Resta L, Leo G, et al: Expression of cathepsin D in malignant and in the corresponding non-malignant nodenegative laryngeal samples: correlation with receptors for androgen, glucocorticoid, oestrogen and progesterone. Cancer Lett 68: 135-142, 1993.

18. Herínk MH and Fuqua SAW: Estrogen receptor mutations in human disease. Endocr Rev 25: 869-898, 2004.

19. Yoo HJ, Sepkovic DW, Bradlow HL, et al: Estrogen metabolism as a risk factor for head and neck cancer. Otolaryngol Head Neck Surg 124: 241-247, 2001

20. Bhatavdekar JM, Patel DD, Vora HH, et al: Prolactin as a local growth promoter in patients with locally advanced tongue cancer: GCRI experience. Head Neck 22: 257-264, 2000.

21. Schiff R, Massarweh SA, Shou J, et al: Cross-talk between estrogen receptor and growth factor pathways as a molecular target for overcoming endocrine resistance. Clin Cancer Res 10 (Suppl.): S331-S336, 2004.

22. Wilson CA and Slamon DJ: Evolving understanding of growth regulation in human breast cancer: interactions of the steroid and peptide growth regulatory pathways. J Natl Cancer Inst 97: 1238-1239, 2005.

23. Rogers SJ, Harrington KJ, Rhys-Evans $\mathrm{P}$, et al: Biological significance of c-erbB family oncogenes in head and neck cancer. Cancer Metastasis Rev 24: 47-69, 2005.

24. Maiorano E, Botticella MA, Marzullo A and Resta L: Expression of ER-D5 and EGFr in laryngeal carcinoma and malignant epithelium. Acta Otolaryngol Suppl 527: 595-599, 1997.

25. Grenman R, Virolainen E, Sharipa A and Carey T: In vitro effects of tamoxifen on UM-SCC head and neck cancer cell lines: correlation with the estrogen and progesterone receptor content. Int J Cancer 39: 77-81, 1987.

26. Ferrandina G, Almadori G, Maggiano N, et al: Growthinhibitory effect of tamoxifen and quercetin and presence of type II estrogen binding stites in human laryngeal cancer cell lines and primary laryngeal tumors. Int $\mathrm{J}$ Cancer 77: 747-754, 1998.

27. Somers KD, Koenig M and Schechter GL: Growth of head and neck squamous cell carcinoma in nude mice: potentiation of laryngeal carcinoma by 17 ß-estradiol. J Natl Cancer Inst 80 : 688-691, 1988. 